\title{
Extracerebral metastases determine the outcome of patients with brain metastases from renal cell carcinoma
}

\author{
Ursula M Vogl ${ }^{1 *}$, Marija Bojic ${ }^{1}$, Wolfgang Lamm¹, Josa M Frischer ${ }^{1}$, Oskar Pichelmayer ${ }^{1}$, Gero Kramer $^{3}$, \\ Andrea Haitel ${ }^{4}$, Klaus Kitz ${ }^{2}$, Kaan Harmankaya ${ }^{5}$, Christoph C Zielinski $^{1}$, Manuela Schmidinger ${ }^{1}$
}

\begin{abstract}
Background: In the era of cytokines, patients with brain metastases (BM) from renal cell carcinoma had a significantly shorter survival than patients without. Targeted agents (TA) have improved the outcome of patients with metastatic renal cell carcinoma (mRCC) however, their impact on patients with BM is less clear. The aim of this analysis was to compare the outcome of patients with and without BM in the era of targeted agents.

Methods: Data from 114 consecutive patients who had access to targeted agent were analyzed for response rates (ORR), progression free survival (PFS) and overall survival (OS). All patients diagnosed with BM underwent local, BMspecific treatment before initiation of medical treatment.

Results: Data of 114 consecutive patients who had access to at least one type of targeted agents were analyzed. Twelve out of 114 renal cell carcinoma (RCC) patients (10.5\%) were diagnosed with BM. Systemic treatment consisted of sunitinib, sorafenib, temsirolimus or bevacizumab. The median PFS was 8.7 months ( $95 \% \mathrm{Cl} 5.1-12.3)$ and 11.4 months ( $95 \% \mathrm{Cl} 8.7$ - 14.1) for BM-patients and non-BM-patients, respectively $(p=0.232)$. The median overall survival for patients with and without BM was $13.4(95 \% \mathrm{Cl} 1-43.9)$ and 33.3 months ( $95 \% \mathrm{Cl} 18.6-47.0)$ ( $\mathrm{p}$ $=0.358$ ), respectively. No patient died from cerebral disease progression. ECOG Performance status and the time from primary tumor to metastases (TDM) were independent risk factors for short survival (HR 2.74, $p=0.001$; HR: $0.552, p=0.034)$.
\end{abstract}

Conclusions: Although extracerebral metastases determine the outcome of patients with BM, the benefit from targeted agents still appears to be limited when compared to patients without BM.

\section{Background}

Brain metastases (BMs) are observed in $2 \%$ to $17 \%$ of patients with metastatic renal cell carcinoma (mRCC) [1]. The majority of these patients present with metastatic disease in multiple organs. Despite the availability of several local treatment strategies for BMs, such as conventional surgery, whole brain radiation therapy (WBRT) and stereotactic radiation (SR), the prognosis of these patients is poor. Patients with BMs were reported to have a median overall survival of 4-5

\footnotetext{
* Correspondence: ursula.vogl@meduniwien.ac.at 'Department of Medicine I, Clinical Division of Oncology and Cancer Center, Medical University Vienna, Vienna, Austria

Full list of author information is available at the end of the article
}

months after diagnosis and treatment of cerebral lesions [2].

Upon diagnosis of BM, patients usually undergo neurosurgical and/or radiotherapeutic procedures whereas medical treatment may be offered later. The choice for a specific type of local treatment depends on the size and number of BMs, their intracerebral location and the patient's condition. Historical data have shown that stereotactic radiation for BMs from renal cell carcinoma (RCC) may result in brain-specific disease control up to 10 months $[3,4]$. Another effective local treatment option is surgery. Most brain metastases from renal cell carcinoma (RCC) are well circumscribed and relatively firm, which makes them suitable for complete surgical resection. Surgical resection was shown to enable a 
median overall survival of more than one year $[1,5]$. In contrast, whole brain radiation appears to confer the smallest benefit in terms of median time to local disease progression (3 to 8 months) [5].

Although surgery or stereotactic radiation may be highly effective to reduce the risk of brain-specific disease progression, BM-patients were shown to have a shorter survival than patients without BM [6]. Interestingly, several authors observed that this was related to the lack of effective medical treatment options with rapid extracerebral disease progression rather than to $\mathrm{BM}$-associated complications such as bleeding or increased brain pressure $[1,2,5,7]$. BM-patients were mostly considered unsuitable for cytokines and only few reports indicate that interferon-alpha (IFN-alpha) and/or interleukin-2 (IL-2) following local BM-treatment may confer survival benefits [7]. These observations suggest that effective medical treatment may account for the outcome of BM-patients rather than the diagnosis of BMs per se.

Therapeutic options for mRCC have tremendously improved in the last 3 years [8-11]. When compared to interferon-alpha, first-line treatment with the tyrosine kinase inhibitor (TKI) sunitinib was shown to significantly improve objective remission rates $(39 \%$ versus $12 \%)$, progression free survival (11 months versus 5 months) and overall survival (26.4 months versus 21.8 months) [12]. Similarly, first-line treatment with the monoclonal antibody bevacizumab in combination with interferon-alpha was shown to provide a statistically significant benefit in overall response rate (ORR) (31\% versus 13\%) and PFS (10.2 months versus 5.4 months) [11] when compared to IFN-alpha alone. In poor risk patients, treatment with the mammalian target of rapamycin (mTOR)-inhibitor temsirolimus was associated with a statistically significant benefit in OS when compared to patients treated with IFN-alpha (10.9 months versus 7.3 months) [10]. In second-line, the tyrosine kinase inhibitor sorafenib was shown to double PFS (5.5 versus 2.8 months, HR: $0.44,95 \%$ CI $0.35-0.55, \mathrm{p}<0.01$ ) when compared to placebo in patients who had progressed on cytokine treatment [9]. Finally, the oral mTOR inhibitor everolimus was shown to reduce the risk for progression in patients who had failed Vascular endothelial growth factor receptor (VEGFR)-based TKI first-line treatment (HR 0.30, 95\%CI: 0.22-0.40) [13]. Patients with BM were excluded from these pivotal trials, however, subsequently initiated smaller studies also investigated the outcome of BM-patients and several authors have shown that sunitinib and sorafenib can be given safely, i.e. without haemorrhage in patients with BMs [6,14-18].

With the advent of these novel agents, extracerebral disease control is enabled in the majority of patients. As patients with $\mathrm{BM}$ are endangered by distant metastases rather than brain metastases, we hypothesized that response rates, progression-free survival and overall survival should be similar in patients with and without BM. The aim of this retrospective analysis was to compare the outcome of patients with and without BM since the start of the era of targeted agents and to investigate whether progression of brain metastases is the most limiting factor for overall survival.

\section{Methods}

All patient data were collected at the Department of Medicine I and Cancer Center, Clinical Division of Oncology at the Medical University of Vienna. This retrospective analysis was performed in accordance with the ethical regulations of the Medical University of Vienna.

\section{Patients}

Data from 114 consecutive mRCC patients who had access to at least one type of targeted agent during their course of the disease were recorded and analyzed for presence of BM at the start of the first targeted agent, response to treatment, progression free survival, overall survival and cause of death. The first novel agent provided and reimbursed was bevacizumab, which was available for off label use in October 2005. Sunitinib, sorafenib, temsirolimus were available later, i.e. in February 2006, June 2006 and March 2007, respectively. The choice for a specific medical treatment was first based on the availability of these agents and later on the results of the pivotal trials. Sunitinib and sorafenib were prescribed at a daily dose of $50 \mathrm{mg}$ (on a 4 weeks on, 2 weeks off schedule) and $800 \mathrm{mg} / \mathrm{d}$ (continuously), respectively. Temsirolimus was prescribed at a weekly dose of $25 \mathrm{mg}$ and bevacizumab every 2 weeks at $10 \mathrm{mg} / \mathrm{kg}$ body weight. Staging investigations were performed at baseline and every 3 months and earlier if clinically required. Response to treatment was evaluated according to the Response Criteria in Solid Tumors (RECIST) [19]. The diagnosis of BMs was made by computed tomography (CT) scan or magnet resonance tomography (MRI).

\section{Statistical methods}

OS was calculated from the start of the first targeted therapy until death. Survival was calculated using the Kaplan-Meier method and groups (no brain metastases versus brain metastases at start of first targeted agent) were compared with the log-rank test. Patient characteristics were compared between the different groups by using the Chi-Square test and the Fisher's Exact test. Multivariate analyses were performed with Cox-Regression. A two-sided p-value lower or equal 0.05 represents significance in all tests. 


\section{Results}

Patient characteristics are outlined in table 1. Between October 2005 and February 2009, 114 consecutive patients with a median age of 65.5 years (range 45-88 years) had access to at least one targeted agent during their course of the disease. The majority of the patients were in good performance status (ECOG 0: 72.8\%) and were intermediate risk (58.7\%) according to the Memorial Sloan-Kettering Cancer Center (MSKCC) criteria [20]. The most common site of metastases was the lung (69.3\%) followed by bone (36\%) and lymph nodes (33.3\%). $47.4 \%$ of the patients had 2 metastatic sites. All but 6 patients had undergone nephrectomy. Sixty-five out of 114 patients (57\%) had prior therapies for metastatic disease consisting of cytokines and/or chemotherapy, another forty-nine patients $(43 \%)$ were treatment naïve. The first targeted agents were mostly sunitinib (63.2\%) and sorafenib (30.7\%). Another 4 and 3 patients received bevacizumab and temsirolimus as the first targeted agent. Twelve out of 114 patients (10.5\%) had - in addition to extracerebral metastases- BM at baseline and underwent local treatment before targeted agents were offered.

\section{Specific characteristics of BM patients at diagnosis of brain metastases}

Specific characteristics of BM patients are shown in Table 2. The median age of BM patients was 66 years. All BM-patients had extracerebral metastases (clear cell $\mathrm{n}=2$, non clear-cell $\mathrm{n}=10$ ), $41.7 \%$ in 2 or more other sites. The most common sites were the lung (67\%) and lymph nodes $(25 \%)$. Six patients $(50 \%)$ had 2 or more cerebral lesions. Brain metastases were mostly located in the cerebellum $(33.3 \%)$ or the frontal lobe $(33.3 \%)$. In $75 \%$ of BM patients, at least one lesion was larger than $2 \mathrm{~cm}$. The majority of BM-patients $(83 \%)$ were symptomatic at diagnosis of BM, the most common symptoms being headache and ataxia. All patients diagnosed with BMs underwent local treatment (surgery only: $\mathrm{n}=2$; stereotactic radiation only: $\mathrm{n}=2$; whole brain radiation only $\mathrm{n}=3$, combinations: $\mathrm{n}=5$ ).

\section{Response to Treatment, Progression Free Survival and Overall Survival}

As outlined in table 3, 33 out of 109 evaluable patients (30.3\%) achieved objective remission under their first targeted agent (complete remission (CR): $n=6$, partial remission (PR): $n=27)$. Another 61 patients (56\%) achieved stable disease (SD) for more than 3 months. Three out of 12 BM-patients (25\%) achieved objective remission (CR: $\mathrm{n}=1$, PR: $\mathrm{n}=2$ ). Another seven patients
Table 1 Baseline characteristics of renal cell carcinoma patients $(n=114)$

\begin{tabular}{lcc}
\hline Characteristics & $\mathbf{N}$ & $\%$ \\
\hline Sex & & \\
male & 69 & 60.5 \\
female & 45 & 39.5 \\
\hline Age & $65.5(45-88)$ & 47.4 \\
median (range) & 54 & 52.6 \\
$<65$ & 60 & \\
$>65$ & & \\
\hline ECOG & 83 & 72.8 \\
0 & 28 & 24.6 \\
1 & 3 & 2.6 \\
2 & & \\
\hline Nephrectomy & 108 & 94.7 \\
Yes & 6 & 5.3 \\
no & &
\end{tabular}

\begin{tabular}{lcc}
\hline Time from primary to metastasis & & \\
$<1$ year & 56 & 49.1 \\
$>1$ year & 58 & 50.9 \\
\hline Histology & & \\
clear cell & 104 & 91.2 \\
non clear cell & 10 & 8.8 \\
\hline MSKCC & & \\
favourable & 45 & 39.5 \\
intermediate & 67 & 58.7 \\
poor & 2 & 1.8
\end{tabular}

\begin{tabular}{llc}
\hline Number of metastasis & & \\
1 & 32 & 28.1 \\
2 & 54 & 47.4 \\
$>3$ & 28 & 24.5 \\
\hline Location of metastasis & & \\
Lung & 79 & 69.3 \\
Liver & 22 & 19.3 \\
Bone & 41 & 36 \\
Lymph nodes (LN) & 38 & 33.3 \\
CNS & 12 & 10.5 \\
Other & 41 & 36 \\
\hline
\end{tabular}

Systemic therapy before first Targeted Agent (TA)

Cytokines $\quad 54 \quad 47.4$

$\begin{array}{lll}\text { other } & 11 & 9.6\end{array}$

First targeted agent

Bevacizumab $\quad 4 \quad 3.5$

$\begin{array}{lll}\text { Sunitinib } & 72 & 63.2\end{array}$

$\begin{array}{lll}\text { Sorafenib } & 35 & 30.7\end{array}$

$\begin{array}{lll}\text { Temsirolimus } & 3 & 2.6\end{array}$ 
Table 2 Specific characteristics of BM patients $(n=12)$

\begin{tabular}{lll}
\hline Age (median, range) & $66(45-88)$ & $\%$ \\
\hline & $\mathbf{n}$ & \\
\hline Number of extracerebral metastatic sites at occurrence of BM & 58.3 \\
-1 & 7 & 16.7 \\
-2 & 2 & \\
$-\geq 3$ & & \\
\hline
\end{tabular}

Location of extracerebral metastases

$\begin{array}{lll}\text { Lung } & 8 & 66.7 \\ \text { Liver } & 2 & 16.7 \\ \text { Bone } & 2 & 16.7 \\ \text { LN } & 3 & 25 \\ \text { other } & 5 & 41.7\end{array}$

Time from primary tumor to occurrence of BM

$<2$ years

$>2$ years

$9 \quad 75$

Number of brain lesions

$\begin{array}{lll}1 & 6 & 50 \\ 2 & 4 & 33.3 \\ >2 & 2 & 16.7\end{array}$

Location of BM metastases

$\begin{array}{lll}\text { - frontal } & 4 & 33.3 \\ \text { - parietal } & 2 & 16.7 \\ \text { - cerebellar } & 4 & 33.3 \\ \text { - temporal } & 1 & 8.3 \\ \text { - dissiminated } & 1 & 8.3\end{array}$

Lesion size

$1 \mathrm{~cm}$

$1-2 \mathrm{~cm}$

$1-8.3$

$>2 \mathrm{~cm}$

$\begin{array}{ll}2 & 16.7\end{array}$

CNS symptom

$\begin{array}{lll}\text { Yes } & 10 & 83.3 \\ \text { No } & 2 & 16.7 \\ \text { - psychiatric } & 1 & 8.3 \\ \text { - vertigo } & 2 & 16.7 \\ \text { - headache } & 5 & 41.7 \\ \text { - ataxia } & 3 & 25 \\ \text { - hemiplegia } & 1 & 8.3\end{array}$

Local treatment for BM

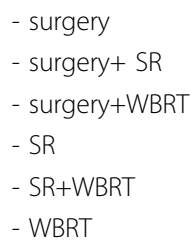

\begin{tabular}{lll}
\hline First targeted agent after local control of BM & & 16.7 \\
- Bevacizumab & 2 & 58.3 \\
- Sunitinib & 7 & 16.7 \\
- Sorafenib & 2 & 8.3 \\
- Temsirolimus & 1 & 8.3 \\
\hline
\end{tabular}


Table 3 Outcome of renal cell carcinoma patients with and without cerebral metastasis

\begin{tabular}{|c|c|c|c|c|c|c|}
\hline & $\begin{array}{c}\text { All patients } \\
n=109 \\
n\end{array}$ & $\%$ & $\begin{array}{c}\text { Patients without } \\
\text { BM } \\
\mathrm{n}=97 \\
\mathrm{n}\end{array}$ & $\%$ & $\begin{array}{c}\text { Patients with BM } \\
n=12 \\
n\end{array}$ & $\%$ \\
\hline \multicolumn{7}{|l|}{ Best response to TA } \\
\hline$-C R$ & 6 & 5.5 & 5 & 5.2 & 1 & 8.3 \\
\hline$-P R$ & 27 & 24.8 & 25 & 25.8 & 2 & 16.7 \\
\hline$-S D$ & 61 & 56 & 54 & 55.7 & 7 & 58.3 \\
\hline \multirow[t]{2}{*}{$-P D$} & 15 & 13.8 & 13 & 13,4 & 2 & 16.7 \\
\hline & $\begin{array}{c}\text { All patients } \\
\mathrm{n}=114 \\
\text { median } \\
\text { (months) }\end{array}$ & $95 \% \mathrm{Cl}$ & $\begin{array}{c}\text { Patients without } \\
\text { BM } \\
\mathrm{n}=102 \text { median } \\
\text { (months) }\end{array}$ & $95 \% \mathrm{Cl}$ & $\begin{array}{l}\text { Patients with BM } n=12 \\
\text { median (months) }\end{array}$ & $95 \% \mathrm{Cl}$ \\
\hline $\begin{array}{l}\text { Progression free survival (start first } \\
\text { TA- progression) }\end{array}$ & 10.9 & $8.3-13.5$ & 11.4 & $8.7-14.1$ & 8.7 & $5.1-12.3$ \\
\hline Overall survival (start first TA- death) & 33.3 & $19.3-47.2$ & 33.3 & $18.6-47.9$ & 13.4 & $1-43.9$ \\
\hline \multicolumn{7}{|l|}{$\mathrm{BM}=$ brain metastases } \\
\hline \multicolumn{7}{|l|}{$\mathrm{TA}=$ targeted agent } \\
\hline \multicolumn{7}{|l|}{$\mathrm{CR}=$ complete response } \\
\hline \multicolumn{7}{|l|}{$\mathrm{PR}=$ partial response } \\
\hline \multirow{2}{*}{\multicolumn{7}{|c|}{$\begin{array}{l}\mathrm{SD}=\text { stable disease } \\
\mathrm{PD}=\text { progressive disease }\end{array}$}} \\
\hline & & & & & & \\
\hline
\end{tabular}

(58.3\%) had SD for at least 3 months. The PFS was 10.9 months (range 8.3-13.5), 11.4 months (8.7-14.1) and 8.7 (5.1-12.3) for the entire population, non-BM-patients and BM-patients, respectively $(\mathrm{p}=0.232)$ (Figure 1$)$. The median overall survival was 33.3 months (95\%CI: 19.3-47.2), 33.3 months (95\%CI: 18.6-47.9) and 13.4 months (95\%CI: 1-43.9) for the entire population, for non-BM and BM patients, respectively $(\mathrm{p}=0.358)$ (Figure 2).

The individual course of disease of BM-patients is outlined in table 4. Three out of 12 BM-patients had a central nervous system (CNS)-relapse and underwent

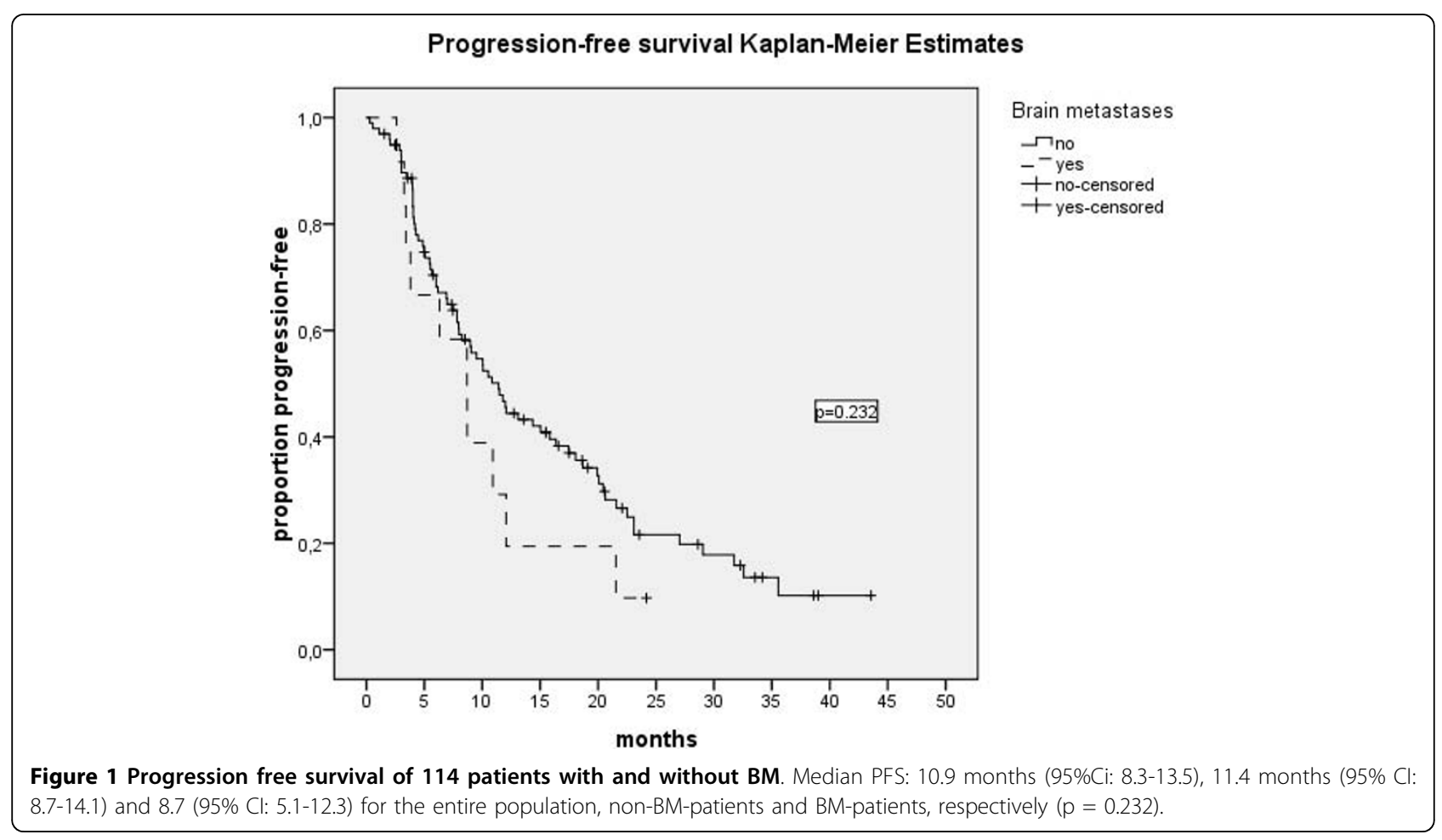




\section{Overall survival Kaplan-Meier Estimates}

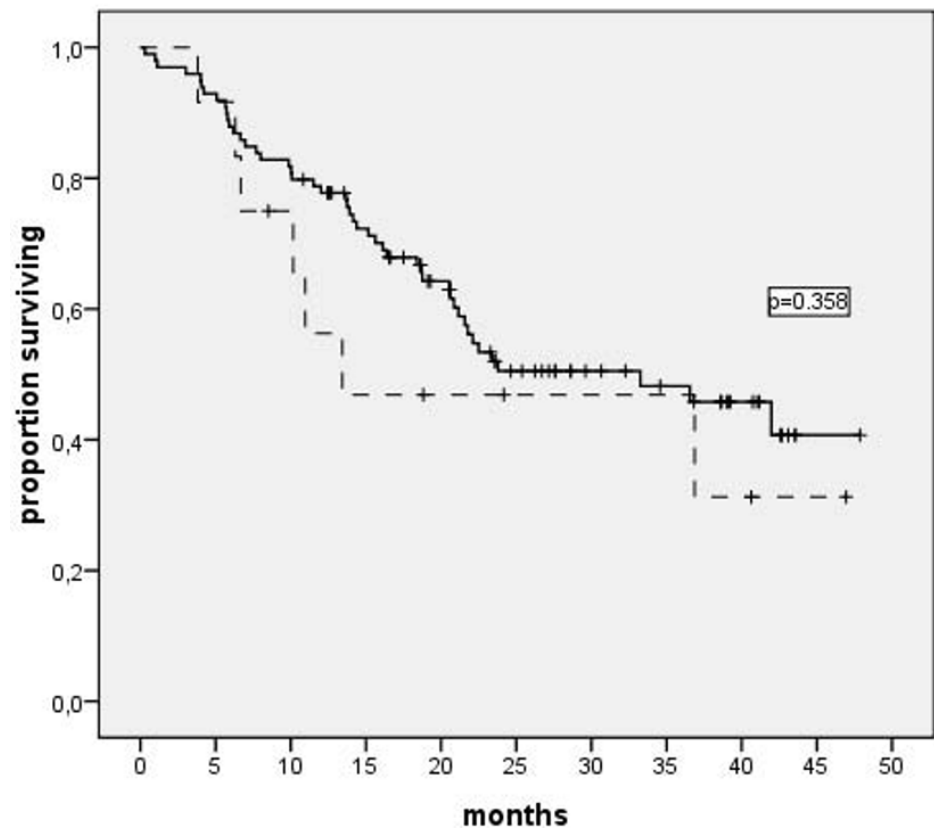

Brain metastases

rno

- yes

+ no-censored

+ yes-censored

Figure 2 Overall survival of $\mathbf{1 1 4}$ patients with and without BM. Median OS: 33.3 months (95\%Cl: 19.3-47.2), 33.3 months (95\%Cl: 18.6-47.9) and 13.4 months (95\%Cl: 1-43.9) for the entire population, for non-BM and BM patients, respectively $(p=0.358)$.

additional local treatment. None of the BM-patients has been diagnosed with or died from BM-specific disease progression since local treatment. ECOG Performance status and the time from primary tumor to metastases were independent risk factors for short survival while no patients died from cerebral disease progression (ECOG Performance status 0: 42 months 95\%CI: 19.33-47.2, ECOG >1: 16.4 months, 95\%CI: 10.3-22.5, Hazard ratio (HR 2.74, $\mathrm{p}=0.001$ ), TDM <1 year: 20.6 months, 95\% CI: 14.1-27.1, and TDM >1 year: 42 months, 95\%CI 32.8-51.2, HR: 0.552, $\mathrm{p}=0.034)$.

\section{CNS-related PFS and BM recurrence}

The median CNS-related PFS (start of local BM-treatment to BM recurrence) is 12.37 months (95\% CI: 149.76). Three out of 12 patients (25\%) had a BM recurrence. Two patients had a progression in lesion size after local treatment and one patient had a relapse of the resected metastasis and new CNS lesions.

\section{Toxicity and treatment-related side effects of BM and non-BM patients}

The most common grade 3 and 4 toxicities in BMpatients were diarrhoea (22.2\%), nausea (11.1\%) and hypertension (11.1\%). In non-BM patients hypertension (19.6\%), hand/foot-syndrome (17.6\%) and diarrhoea $(12.8 \%)$ were the most common grade 3 and 4 toxicities.

\section{Discussion}

In the era of cytokine treatment, extracerebral metastases rather than brain metastases were shown to determine the course of disease in patients with advanced RCC and brain lesions. Most patients with BM either did not benefit from cytokine treatment or were considered unsuitable for cytokines [21]. The advent of targeted agents for RCC has enabled significantly better control of systemic disease [8-11, 13]. Thus we hypothesized that patients with and without BM may have similar benefits from modern agents. We found that targeted agents led to quite similar response rates in patients with and without BM. However, the median progression free survival and overall survival were strikingly lower in patients with BM when compared to patients without (PFS: 8.7 versus 11.4 months, $\mathrm{p}=$ 0.232 , OS: 13.4 months versus 33.3 months, $\mathrm{p}=0.358$ ). A limitation of our report is the variety of local and systemic therapies offered (i.e. stereotactic radiosurgery or WBRT, sunitinib, sorafenib, bevacizumab and temsirolimus). Moreover, differences in PFS and OS did not reach statistical significance due to the small number of patients. However, our findings are consistent with other reports. In the sunitinib extended access program, the median progression free survival and overall survival for the entire population were 10.9 and 18.4 months, respectively, whereas the subgroup of patients with BM 
Table 4 Individual course of disease of BM patients

\begin{tabular}{|c|c|c|c|c|c|c|c|c|c|c|c|c|c|}
\hline Patient & $\begin{array}{l}\text { MSKCC } \\
\text { risk } \\
\text { group }\end{array}$ & $\begin{array}{l}\text { ECOG } \\
\text { performance } \\
\text { status at } \\
\text { diagnosis of } \\
\text { BM }\end{array}$ & $\begin{array}{l}\text { Extracerebral } \\
\text { metastatic } \\
\text { site }\end{array}$ & $\begin{array}{l}\text { TX prior } \\
\text { first TA }\end{array}$ & $\begin{array}{l}\text { Time from } \\
\text { primary } \\
\text { metastasis } \\
\text { to BM } \\
\text { (months) }\end{array}$ & $\begin{array}{l}\text { BM- } \\
\text { TX }\end{array}$ & $\begin{array}{l}\text { CNS } \\
\text { recurrence } \\
\text { during/after } \\
\text { TA }\end{array}$ & $\begin{array}{l}\text { First } \\
\text { TA }\end{array}$ & $\begin{array}{l}\text { Best } \\
\text { Response }\end{array}$ & PFS & $\begin{array}{l}\text { Following } \\
\text { TX lines }\end{array}$ & os & $\begin{array}{l}\text { Progressing } \\
\text { metastatic } \\
\text { site leading } \\
\text { to death }\end{array}$ \\
\hline 1 & fav & 0 & Lung & Cytokines & 0 & surg & no & SU & $C R$ & 24.2 & Ongoing & 24.2 & $\begin{array}{l}\text { non } \\
\text { progressing } \\
\text { and alive } \\
\end{array}$ \\
\hline 2 & interm & 0 & Lung & $\begin{array}{l}\text { Cytokines, } \\
\text { Capecitabin }\end{array}$ & 45 & surg & no & Beva & SD & 8.7 & $\begin{array}{l}\text { SU } \\
\text { Soraf } \\
\text { Tems } \\
\text { Tems+Beva }\end{array}$ & 46.9 & $\begin{array}{l}\text { non } \\
\text { progressing } \\
\text { and alive }\end{array}$ \\
\hline 3 & interm & 1 & lung, LN & no & 0 & $\begin{array}{l}\text { surg, } \\
\text { WBRT }\end{array}$ & no & SU & SD & 8.5 & ongoing & 8.5 & $\begin{array}{l}\text { non } \\
\text { progressing } \\
\text { and alive }\end{array}$ \\
\hline 4 & interm & 1 & lung, other & Cytokines & 72 & $S R$ & no & Beva & SD & 21.6 & SU, Tems & 36.9 & lung, liver \\
\hline 5 & fav & 0 & $\begin{array}{l}\text { liver, bone, } \\
\text { other }\end{array}$ & $\begin{array}{l}\text { Cytokines, } \\
\text { Navelbine }\end{array}$ & 27 & $\begin{array}{l}\text { WBRT, } \\
\text { SR }\end{array}$ & $\begin{array}{l}\text { yes } \\
\text { (progression } \\
\text { in lesion } \\
\text { size) }\end{array}$ & Soraf & PD & 2.6 & SU & 13.42 & lung. \\
\hline 6 & interm & 1 & other & no & 0 & $\begin{array}{l}\text { SR, } \\
\text { WBRT }\end{array}$ & $\begin{array}{l}\text { yes } \\
\text { (progression } \\
\text { in lesion } \\
\text { size) }\end{array}$ & SU & PD & 3.4 & $\begin{array}{l}\text { Tems, Beva } \\
\text { +Interferon }\end{array}$ & 10.16 & Liver \\
\hline 7 & interm & 0 & $\mathrm{Ln}$ & no & 0 & WBRT & no & SU & PR & 3.26 & Soraf & 18.82 & $\begin{array}{l}\text { non } \\
\text { progressing } \\
\text { and alive }\end{array}$ \\
\hline 8 & interm & 1 & lung & no & 0 & $\begin{array}{l}\text { Surg, } \\
\text { SR }\end{array}$ & no & SU & SD & 12.1 & SU & 40.6 & $\begin{array}{l}\text { non } \\
\text { progressing } \\
\text { and alive }\end{array}$ \\
\hline 9 & interm & 1 & $\begin{array}{l}\text { lung, liver, } \\
\text { other }\end{array}$ & no & 0 & SR & no & Tems & SD & 6.3 & no & 6.3 & liver, lung \\
\hline 10 & interm & 0 & lung, In & no & 8 & WBRT & no & Soraf & PR & 10.9 & no & 10.9 & Lung \\
\hline 11 & interm & 0 & lung, other & $\begin{array}{l}\text { Cytokines, } \\
\text { Navelbine }\end{array}$ & 14 & $\begin{array}{l}\text { Surg, } \\
\text { WBRT }\end{array}$ & $\begin{array}{l}\text { yes (relapse } \\
\text { of resected } \\
\text { lesion and } \\
\text { new lesions) }\end{array}$ & SU & SD & 3.8 & no & 3.8 & $\begin{array}{l}\text { cranial } \\
\text { vertebral } \\
\text { fractures }\end{array}$ \\
\hline 12 & poor & 2 & bone & no & 0 & WBRT & $\mathrm{No}$ & SU & SD & 6.7 & no & 6.7 & Lung \\
\hline
\end{tabular}

MSKCC = Memorial Sloan-Kettering Center Center

fav $=$ favourable risk

interm $=$ intermediate risk

poor $=$ poor risk

ECOG = Eastern Cooperative Oncology Group

$\mathrm{TX}=$ treatment

$\mathrm{TA}=$ targeted agent

$\mathrm{BM}=$ brain metastasis

$\mathrm{SR}=$ stereotactic radiation

WBRT $=$ whole brain radiation therapy

Surg = surgery

$\mathrm{SU}=$ Sunitinib

Soraf $=$ Sorafenib

Tems $=$ Temsirolimus

Beva $=$ Bevacizumab

$\mathrm{CR}=$ complete remission

$\mathrm{PR}=$ partial remission

$\mathrm{SD}=$ stable disease

$\mathrm{PD}=$ progressive disease

$\mathrm{PFS}=$ progression free survival

OS $=$ overall survival 
was shown to achieve a median PFS and OS of 5.6 and 9.2 months, only [6].

Although (radio-) surgery was shown to provide excellent local control in up to $96 \%$ of the patients $[1,22]$, it would be expected that reduced overall survival of BMpatients is related to the tenuous site of metastases. This is supported by the report of Sperduto and colleagues who found that the number of cerebral lesions is an independent prognostic factor in patients with RCC [23]. Brain metastases may dramatically endanger the patient by leading to local edema, increased intracranial pressure and fatal bleeding. However, in our series, brain metastases per se were not responsible for shorter survival of these patients. All patients with BMs were neurologically unsuspicious in the last 24 hours before death and died obviously from disease progression of extracerebral metastatic sites, leading most commonly to respiratory or hepatic failure. Among those who are alive, none is endangered by intracerebral disease progression. Hence, the presence of BM was not a risk factor for shorter overall survival $(p=0.358)$. In the multivariate analysis, only ECOG Performance status (ECOG 0: 42 months 95\%CI: 19.33-47.2, ECOG $>1: 16.4$ months, 95\%CI: 10.3.22.5, HR: 2.74, $\mathrm{p}=0.001$ ) and the time from primary tumor to development of metastases (< 1 year: 20.6 months, $95 \%$ CI $14.1-27.1$, and $>1$ year: 42 months, 95\%CI 32.8-51.2, HR: 0.552, $\mathrm{p}=0.034$ ) were independent risk factors for short survival. Our results are consistent with the findings of Hara et al. who reported that a poor performance status accounts for shorter survival of BM-patients rather than the presence of brain metastases per se [22]. Consequently the authors suggested that effective therapeutic strategies for systemic disease may prolong survival in patients with locally treated brain metastases.

Although all patients of the present analysis had access to at least one type of effective RCC treatment leading to stable disease or objective remission in the majority and while no patient died from BM-related progression, the outcome is still different between $B M$ and non-BM-patients. Several reasons may account for these differences. First, brain metastases were shown to occur late in the progression of mRCC [24]. Consequently, the overall survival of these patients may often reflect only the length of the very last life span within the course of metastatic disease. Second, the occurrence of brain metastases may represent an epiphenomenon of an altered, meanwhile highly aggressive behaviour of the tumor. Hence, it could be speculated that patients with $\mathrm{BM}$ require far more aggressive treatment strategies than patients without and that alternative therapeutic targets may become more relevant. In this context, the signal transducer and activator of transcription 3 (Stat3) might be an interesting target. Activation of Stat3 was shown to be increased in brain metastases [25]. Sunitinib inhibits Stat 3 in both tumor cells and tumor myeloid cells [26], thereby leading to tumor cell apoptosis and reduced expression of angiogenic genes and immunosuppressive cells. However, persistent Stat 3 activation has been shown to rescue tumor cells from sunitinibinduced cell death [26] and to promote cell proliferation by regulating genes encoding antiapoptotic and proliferation-associated proteins [27]. Patients with brain metastases and activated Stat 3 may require a treatment strategy that inhibits Stat3 in various ways. A combination of sunitinib with an anti-interleukin- 6 antibody has been suggested, since Stat3-activation is mediated by the interleukin-6 receptor [26]. Another promising target whose expression correlates with advanced stage of disease is the chemokine receptor CXCR4, a key receptor in the crosstalk between tumor cells and their environment [28]. In RCC, the loss of function of the Von Hippel Lindau ( $V H L)$ tumor supressor gene mediates upregulation of CXCR4 [29] which then promotes tumor spread and progression [28]. The activity of CXCR4directed agents has already been shown in animal tumor models [30] and might be of particular interest in rapidly progressing tumors.

\section{Conclusions}

Despite both excellent neuro(radio-)surgical strategies and advances in the treatment of systemic mRCC, the course of disease of patients with brain metastases remains an enormous challenge. These patients are endangered by rapidly progressing extracerebral metastases rather than progressing brain metastases. Thus, different i.e. more complex therapeutic concepts are urgently required for this patient population and baseline and repeated CT-scans of the brain should be provided in all patients in order to enable highly potent local treatment options.

\section{Declaration of competing interests}

Manuela Schmidinger has acted as an adviser to Pfizer, Bayer-Schering, Wyeth, Novartis, Roche and GSK, has received research grants from Pfizer and Wyeth, travel grants from Bayer-Schering and Wyeth and lecture fees from Pfizer, Bayer-Schering, Novartis, Roche and Wyeth. Christoph Zielinski has acted as an adviser to Pfizer and Roche, has received lecture fees from Pfizer, Merck, Lilly and Roche and research grants from Pfizer and Wyeth. Gero Kramer has received research grants from Sanofi Aventis, Bayer-Schering and Takeda, lecture fees from Sanofi Aventis, Astra Zeneca and Astellas, acted as an advisor to Sanofi Aventis and received travel grants from Pfizer, Boehringer-Ingelheim, Sanofi Aventis and Bayer-Schering. Ursula Vogl has received travel grants from Pfizer, Wyeth Roche and Bayer-Schering. 
Wolfgang Lamm has received travel grants from BayerSchering. Oskar Pichelmayer has received research grants from Roche and travel grants from Bayer-Schering. Marija Bojic, Andrea Haitel, Josa Frischer, Kaan Harmankaya and Klaus Kitz have no conflicts of interest to declare.

\section{Role of the funding source}

The study was sponsored by the Medical University of Vienna, who had no involvement in the design, conduct, data collection and data analysis. The corresponding author had access to all data and takes responsibility for the accuracy and completeness of the data reported. The corresponding author had final responsibility for the decision to submit for publication.

\section{Author details \\ 1Department of Medicine I, Clinical Division of Oncology and Cancer Center, Medical University Vienna, Vienna, Austria. ²Department of Neurosurgery, Medical University Vienna, Vienna, Austria. ${ }^{3}$ Department of Urology, Medical University Vienna, Vienna, Austria. ${ }^{4}$ Department of Pathology, Medical University Vienna, Vienna, Austria. ${ }^{5}$ Department of Dermatology, Medical University Vienna, Vienna, Austria.}

\section{Authors' contributions}

UMV originally conceived of the study design, recruited the patients, collected and reviewed the clinical data, analyzed and interpreted the results, wrote the manuscript, participated in table and figure conception and oversight the entire project. MB participated in patient recruitment, collection and review of clinical data, clinical data analysis, clinical figure design, project coordination and biostatistical analysis. WP participated in patient recruitment, collection and review of clinical data and project coordination. WL participated in patient recruitment, collection and review of clinical data and project coordination. JMF participated in clinical data analysis, clinical table and figure design and biostatistical analysis. $\mathrm{AH}$ participated in patient recruitment, collection and review of clinical data, clinical data analysis and interpretation and project coordination. GK participated in clinical study design, collection and review of clinical data, clinical data analysis and interpretation and project coordination. $\mathrm{KH}$ participated in patient recruitment, collection and review of clinical data and clinical data interpretation. MS and CCZ participated in patient recruitment, review of clinical data, clinical data interpretation, manuscript writing and project coordination.

All authors have and approved the final manuscript.

Received: 20 January 2010 Accepted: 7 September 2010

Published: 7 September 2010

\section{References}

1. Sheehan JP, Sun MH, Kondziolka D, Flickinger J, Lunsford LD: Radiosurgery in patients with renal cell carcinoma metastasis to the brain: long-term outcomes and prognostic factors influencing survival and local tumor control. J Neurosurg 2003, 98(2):342-349.

2. Shuch B, La Rochelle JC, Klatte T, Riggs SB, Liu W, Kabbinavar FF, Pantuck AJ, Belldegrun AS: Brain metastasis from renal cell carcinoma: presentation, recurrence, and survival. Cancer 2008, 113(7):1641-1648.

3. Clarke JW, Register S, McGregor JM, Grecula JC, Mayr NA, Wang JZ, Li K, Gupta N, Kendra KL, Olencki TE, Cavaliere R, Sarkar A, Lo SS: Stereotactic Radiosurgery With or Without Whole Brain Radiotherapy for Patients With a Single Radioresistant Brain Metastasis. Am J Clin Oncol 2009.

4. Marko NF, Angelov L, Toms SA, Suh JH, Chao ST, Vogelbaum MA, Barnett GH, Weil RJ: Stereotactic radiosurgery as single-modality treatment of incidentally identified renal cell carcinoma brain metastases. Surg Neurol 2009.
5. Wronski M, Arbit E, Russo P, Galicich JH: Surgical resection of brain metastases from renal cell carcinoma in 50 patients. Urology 1996, 47(2):187-193.

6. Gore ME, Szczylik C, Porta C, Bracarda S, Bjarnason GA, Oudard S, Hariharan S, Lee SH, Haanen J, Vrdoljak E, Schöffski P, Mainwaring P, Nieto A, Yuan J, Bukowski R: Safety and efficacy of sunitinib for metastatic renal-cell carcinoma: an expanded-access trial. Lancet Oncol 2009, 10(8):757-763.

7. Mori Y, Kondziolka D, Flickinger JC, Logan T, Lunsford LD: Stereotactic radiosurgery for brain metastasis from renal cell carcinoma. Cancer 1998, 83(2):344-353.

8. Motzer RJ, Hutson TE, Tomczak P, Michaelson MD, Bukowski RM, Rixe O, Oudard S, Negrier S, Szczylik C, Kim ST, Chen I, Bycott PW, Baum CM, Figlin RA: Sunitinib versus interferon alfa in metastatic renal-cell carcinoma. N Engl J Med 2007, 356(2):115-124.

9. Escudier B, Eisen T, Stadler WM, Szczylik C, Oudard S, Siebels M, Negrier S, Chevreau C, Solska E, Desai AA, Rolland F, Demkow T, Hutson TE, Gore M, Freeman S, Schwartz B, Shan M, Simantov R, Bukowski RM, TARGET Study Group: Sorafenib in advanced clear-cell renal-cell carcinoma. N Engl J Med 2007, 356(2):125-134.

10. Hudes G, Carducci M, Tomczak P, Dutcher J, Figlin R, Kapoor A, Staroslawska E, Sosman J, McDermott D, Bodrogi I, Kovacevic Z, Lesovoy V, Schmidt-Wolf IG, Barbarash O, Gokmen E, OToole T, Lustgarten S, Moore L, Motzer RJ, Global ARCC Trial: Temsirolimus, interferon alfa, or both for advanced renal-cell carcinoma. N Engl J Med 2007, 356(22):2271-2281.

11. Escudier B, Pluzanska A, Koralewski P, Ravaud A, Bracarda S, Szczylik C, Chevreau C, Filipek M, Melichar B, Bajetta E, Gorbunova V, Bay JO, Bodrogi I, Jagiello-Gruszfeld A, Moore NT, AVOREN rial investigators: Bevacizumab plus interferon alfa-2a for treatment of metastatic renal cell carcinoma: a randomised, double-blind phase III trial. Lancet 2007, 370(9605):2103-2111.

12. Motzer RJ, Hutson TE, Tomczak P, Michaelson MD, Bukowski RM, Oudard S, Negrier S, Szczylik C, Pili R, Bjarnason GA, Garcia-del-Muro X, Sosman JA, Solska E, Wilding G, Thompson JA, Kim ST, Chen I, Huang X, Figlin RA: Overall survival and updated results for sunitinib compared with interferon alfa in patients with metastatic renal cell carcinoma. J Clin Oncol 2009, 27(22):3584-3590.

13. Motzer RJ, Escudier B, Oudard S, Hutson TE, Porta C, Bracarda S, Grunwald V, Thompson JA, Figlin RA, Hollaender N, Urbanowitz G, Berg WJ, Kay A, Lebwohl D, Ravaud A, RECORD-1 Study Group: Efficacy of everolimus in advanced renal cell carcinoma: a double-blind, randomised, placebo-controlled phase III trial. Lancet 2008, 372(9637):449-456

14. Helgason HH, Mallo HA, Droogendijk H, Haanen JG, van der Veldt AA, van den Eertwegh AJ, Boven E: Brain metastases in patients with renal cell cancer receiving new targeted treatment. J Clin Oncol 2008, 26(1):152-154

15. Medioni J, Cojocarasu O, Belcaceres JL, Halimi P, Oudard S: Complete cerebral response with sunitinib for metastatic renal cell carcinoma. Ann Oncol 2007, 18(7):1282-1283.

16. Koutras AK, Krikelis D, Alexandrou N, Starakis I, Kalofonos HP: Brain metastasis in renal cell cancer responding to sunitinib. Anticancer Res 2007, 27(6C):4255-4257.

17. Valcamonico F, Ferrari $V$, Amoroso $V$, Rangoni $G$, Simoncini $E$, Marpicati $P$, Vassalli L, Grisanti S, Marini G: Long-lasting successful cerebral response with sorafenib in advanced renal cell carcinoma. J Neurooncol 2009, 91(1):47-50.

18. Hariharan S: Sunitinib in metastatic renal cell carcinoma (mRCC) patients (pts) with brain metastases (mets): data from an expanded access trial. $J$ Clin Oncol 2008, 26:5094, (May 20 suppl):abstr.

19. Eisenhauer EA, Therasse P, Bogaerts J, Schwartz LH, Sargent D, Ford R, Dancey J, Arbuck S, Gwyther S, Mooney M, Rubinstein L, Shankar L, Dodd L, Kaplan R, Lacombe D, Verweij J: New response evaluation criteria in solid tumours: revised RECIST guideline (version 1.1). Eur J Cancer 2009, 45(2):228-247.

20. Motzer RJ, Bacik J, Murphy BA, Russo P, Mazumdar M: Interferon-alfa as a comparative treatment for clinical trials of new therapies against advanced renal cell carcinoma. J Clin Oncol 2002, 20(1):289-296.

21. Bukowski RM, Young J, Goodman G, Meyers F, Issell BF, Sergi JS, McLain D, Fyfe G, Finke J: Polyethylene glycol conjugated interleukin-2: clinical and 
immunologic effects in patients with advanced renal cell carcinoma. Invest New Drugs 1993, 11(2-3):211-217.

22. Hara W, Tran P, Li G, Su Z, Puataweepong P, Adler JR, Soltys SG, Chang SD, Gibbs IC: Cyberknife for brain metastases of malignant melanoma and renal cell carcinoma. Neurosurgery 2009, 64(2 Suppl):A26-32.

23. Sperduto PW, Chao ST, Sneed PK, Luo X, Suh J, Roberge D, Bhatt A, Jensen AW, Brown PD, Shih H, Kirkpatrick J, Schwer A, Gaspar LE, Fiveash JB, Chiang V, Knisely J, Sperduto CM, Mehta M: Diagnosis-Specific Prognostic Factors, Indexes, and Treatment Outcomes for Patients with Newly Diagnosed Brain Metastases: A Multi-Institutional Analysis of 4,259 Patients. Int I Radiat Oncol Biol Phys 2009.

24. Fidler IJ, Yano S, Zhang RD, Fujimaki T, Bucana CD: The seed and soil hypothesis: vascularisation and brain metastases. Lancet Oncol 2002 3(1):53-57.

25. Xie TX, Huang FJ, Aldape KD, Kang SH, Liu M, Gershenwald JE, Xie K, Sawaya R, Huang S: Activation of stat 3 in human melanoma promotes brain metastasis. Cancer Res 2006, 66(6):3188-3196.

26. Xin H, Zhang C, Herrmann A, Du Y, Figlin R, Yu H: Sunitinib inhibition of Stat 3 induces renal cell carcinoma tumor cell apoptosis and reduces immunosuppressive cells. Cancer Res 2009, 69(6):2506-2513.

27. Niu G, Wright KL, Huang M, Song L, Haura E, Turkson J, Zhang S, Wang T, Sinibaldi D, Coppola D, Heller R, Ellis LM, Karras J, Bromberg J, Pardoll D, Jove R, Yu H: Constitutive Stat3 activity up-regulates VEGF expression and tumor angiogenesis. Oncogene 2002, 21(13):2000-2008.

28. Burger JA, Kipps TJ: CXCR4: a key receptor in the crosstalk between tumor cells and their microenvironment. Blood 2006, 107(5):1761-1767.

29. Zagzag D, Krishnamachary B, Yee H, Okuyama H, Chiriboga L, Ali MA, Melamed J, Semenza GL: Stromal cell-derived factor-1alpha and CXCR4 expression in hemangioblastoma and clear cell-renal cell carcinoma: von Hippel-Lindau loss-of-function induces expression of a ligand and its receptor. Cancer Res 2005, 65(14):6178-6188.

30. Takenaga M, Tamamura H, Hiramatsu K, Nakamura N, Yamaguchi Y, Kitagawa A, Kawai S, Nakashima H, Fujii N, Igarashi R: A single treatment with microcapsules containing a CXCR4 antagonist suppresses pulmonary metastasis of murine melanoma. Biochem Biophys Res Commun 2004, 320(1):226-232.

\section{Pre-publication history}

The pre-publication history for this paper can be accessed here: http://www.biomedcentral.com/1471-2407/10/480/prepub

doi:10.1186/1471-2407-10-480

Cite this article as: Vogl et al: Extracerebral metastases determine the outcome of patients with brain metastases from renal cell carcinoma. BMC Cancer 2010 10:480.

\section{Submit your next manuscript to BioMed Central and take full advantage of:}

- Convenient online submission

- Thorough peer review

- No space constraints or color figure charges

- Immediate publication on acceptance

- Inclusion in PubMed, CAS, Scopus and Google Scholar

- Research which is freely available for redistribution

Submit your manuscript at www.biomedcentral.com/submit
Ciomed Central 